This item was submitted to Loughborough's Research Repository by the author.

Items in Figshare are protected by copyright, with all rights reserved, unless otherwise indicated.

\title{
Positive youth development and physical activity/sport interventions: mechanisms leading to sustained impact
}

\section{PLEASE CITE THE PUBLISHED VERSION}

http://dx.doi.org/10.1080/17408989.2012.666791

\section{PUBLISHER}

Taylor and Francis / @ Association for Physical Education

\section{VERSION}

AM (Accepted Manuscript)

\section{PUBLISHER STATEMENT}

This work is made available according to the conditions of the Creative Commons Attribution-NonCommercialNoDerivatives 4.0 International (CC BY-NC-ND 4.0) licence. Full details of this licence are available at: https://creativecommons.org/licenses/by-nc-nd/4.0/

\section{LICENCE}

CC BY-NC-ND 4.0

\section{REPOSITORY RECORD}

Armour, Kathleen, Rachel A. Sandford, and Rebecca Duncombe. 2019. "Positive Youth Development and Physical Activity/sport Interventions: Mechanisms Leading to Sustained Impact". figshare. https://hdl.handle.net/2134/19790. 
Running head: PYD, physical activity interventions and sustained impact

Positive Youth Development and Physical Activity/Sport Interventions: Mechanisms Leading to

Sustained Impact

\section{Abstract}

5 Sport/physical activity interventions are sometimes viewed as a panacea for youth-related social

6 problems, and this may explain their proliferation. Yet, there is little robust evidence to support some

7 of the claims made for the efficacy of such programmes, particularly those relating to sustained benefits

8 for young people. The purpose of this paper is to report findings from longitudinal research on two

9 youth sport/physical activity interventions in the UK in order identify key features in their design that

10 were found to be central to sustained positive impact. The physical activity programmes sought to

11 address youth disaffection and disengagement and they were evaluated by one research team using a

12 common evaluation strategy. Both programme sponsors were committed to learning from the

13 evaluation findings and to wider dissemination. The programmes are explained, data on sustainability

14 of impact are reported from each project and the findings considered together to identify common

15 themes. Data suggest that six key features should be embedded in the design of physical

16 activity/positive youth development programmes and that, in combination and through complex

17 interaction, they can maximise the potential for sustained positive impact on youth participants.

19 Keywords: positive youth development; youth disaffection; physical activity programmes;

20 programme evaluation; sustained impact. 
Running head: PYD, physical activity interventions and sustained impact

21 Positive Youth Development and Physical Activity/Sport Interventions: Mechanisms leading to

Sustained Impact

Introduction

There has been significant concern in contemporary society about 'problematic' behaviour among young people, and growing levels of youth disaffection and disengagement (DSS, 1999; SEU,

27 2000; Steer, 2000; Newburn \& Shiner, 2005). Certainly, within the UK, youth disaffection is a frequent 28 topic of discussion in public discourse, often fuelled by media representations of disruptive, 29 disrespectful and dangerous young people. This has led to both political debate and the formation of 30 government policy (Sandford, Duncombe \& Armour, 2008). In particular, worries about young

31 people's involvement in anti-social or criminal behaviour, their disengagement from education/training 32 and their perceived lack of civic engagement and responsibility have heightened concerns regarding the 33 potential impact on social order (DfES, 2003a,b; Davies, 2005; Newburn \& Shiner, 2005; France, 34 2007). Such concerns, however, are not confined to the UK. Indeed, debates concerning youth 35 disaffection, disengagement and perceived anti-social behaviour abound in a number of fields and 36 disciplines across the Western world (Smink, 2000; Sandford, Armour \& Warmington, 2006).

37 Moreover, as Newburn \& Shiner (2005) point out, panic concerning 'problematic' youth is not new but 38 has prevailed throughout history. The intensity of current concerns, however, has led to calls for 39 'action' to address the issue. Engagement in sport and other forms of physical activity has traditionally been credited with

41 having a particularly valuable role in tackling youth disaffection and disengagement (France et al., 42 2007). This seems to be rooted in the belief that sport encourages moral and social responsibility, pro43 social behaviours and respect for others (Eley and Kirk, 2002; Russell, 2004). Such beliefs are 44 heightened in the case of 'Outward Bound' activities where it is often argued that the challenge 45 inherent in such activities offers unique learning opportunities (Neill \& Dias, 2001). The two 46 programmes reported in this paper used a mixture of sport, outward bound and other physical activities 
Running head: PYD, physical activity interventions and sustained impact

47 to engage young people. The aspirations for young people governing both programmes were, however,

48 almost identical, including a strong focus on generating positive outcomes for young people that could

49 be sustained over time.

Ruiz (2004) among others has pointed to the difficulty of linking participation in sport and

51 physical activity to the wide ranging impacts that are often claimed by intervention programmes and,

52 along with others, has argued for more - and more robust - research evidence (Bailey, 2005; Holt \&

53 Jones, 2008). The two programmes evaluated in this paper were somewhat unique in that both sponsors

54 funded independent longitudinal evaluation projects and expressed a strong interest in learning from

55 the data and sharing findings more widely. Nonetheless, as is reported in detail in section (iii), the

56 broad aims of the programmes and the flexibility offered to participants made the evaluation

57 particularly challenging.

58 This paper has the dual purpose of identifying the themes from the data that contributed to the

59 reported sustained impact on participants, and analysing the complex ways in which these themes

60 interacted in these two programmes. Thus, the paper can contribute to the knowledge base on the ways

61 in which such programmes can be designed to maximise the potential for sustained impact. The paper

62 is organised into five main sections: (i) An overview of the underpinning theory related to using sport

63 and physical activity programmes as a form of positive youth development; (ii) a description of the two

64 programmes evaluated; (iii) the methodological framework for the evaluation; (iv) findings on

65 sustainable impact reported from each programme; and (v) discussion on the complex ways in which

66 the six key programme design features interacted in order to facilitate sustained positive impact on

67 youth participants.

Theoretical Underpinnings: Physical Activity/Sport for Positive Youth Development

70 Within the UK, moral panic has resulted in a raft of policies, programmes and government measures

71 intended to tackle the problem of youth disaffection and facilitate young people's re-engagement and

72 positive development (see Sandford, Duncombe \& Armour 2008 for a detailed discussion). 
Running head: PYD, physical activity interventions and sustained impact

73 Interestingly, many of these policies and programmes (e.g. PESSCL, Positive Futures, NOPES ${ }^{i}$ )

74 involve the use of sport and physical activity interventions as tools to be used to enhance personal

75 development. This would appear to be rooted in the long standing belief that engagement in sport, in

76 particular, can instil character, develop positive attributes, enhance moral development and secure

77 wide-ranging benefits for disengaged young people (Martinek \& Hellison, 1997; Miller, Bredemeier \&

78 Shields, 1997; Burt, 1998; Theodoulides \& Armour, 2001; Eley \& Kirk, 2002; Holt, 2008). Moreover,

79 given its potential to reach large and diverse groups of young people, school physical education has

80 also come to be viewed as an important context in which disaffected pupils can be re-engaged (Bailey,

81 2005; France et al., 2007). Indeed, a recent UK government report reinforced the perceived

82 significance of physical education and school sport (PESS) for tackling youth disaffection, suggesting

83 that it can help to, among other things, improve behaviour, attendance and educational attainment

84 (DCMS, 2007).

85 Outside of government generated programmes, the 'social problems industry', driven by the belief 86 that physical activities can address social concerns (Pitter \& Andrews, 1997) has resulted in numerous

87 independent or corporate-sponsored initiatives (such as those outlined in this paper) designed to re-

88 engage disaffected youth through participation in structured physical activities. Many of these

89 programmes make use of outdoor or adventurous physical activities, reflecting a belief in their positive

90 youth development potential. Indeed, there is a significant body of literature available on the use of

91 outdoor/adventurous activities as a means of promoting youth personal development (Nichols, 1997;

92 Garst, Schneider \& Baker, 2001; Newton, Sandberg \& Watson, 2001). Moreover, claims regarding the

93 educational value of Outward Bound programs have been the focus of a number of evaluation studies.

94 Hattie et al., (1997), for example, concluded that there was sufficient evidence to suggest that Outward

95 Bound programmes were able to have a positive impact on individuals (for example, in relation to

96 increased confidence, leadership and communication skills) and that there was some potential for these

97 impacts to be sustained over time. 
Running head: PYD, physical activity interventions and sustained impact

Around the world there are further examples of sport, physical activity and physical education

99 programmes being used to facilitate positive development and re-engage young people in education and 100 society more broadly. Examples from the US include Siedentop’s (1994) Sport Education, Hellison’s

101 (1995) Teaching Personal and Social Responsibility, and Ennis’ (1999) Sport for Peace. Bailey (2008)

102 has argued that findings from the evaluations of programs such as these are "cautiously optimistic"

103 (p.89). Research has indicated the propensity for such programmes to facilitate, among other things, an

104 increased sense of belonging, a respect for both self and others, a more positive attitude to physical

105 activity/physical education and a shared responsibility for learning (Ennis et al., 1999; Hellison \&

106 Walsh, 2002; MacPhail, Kirk \& Kinchin, 2004). In addition, some studies have pointed to the potential

107 of physical activity/physical education to contribute, more specifically, to young people's socio-moral

108 development. For example, in their review of the 'Fair Play for Kids' program, Gibbons, Ebbeck \&

109 Weiss (1995) noted that participation could be seen to effect positive change on the moral development

110 of pupils.

111 While such findings are encouraging, it has also been argued that more research is required to

112 explore the long-term impact of program participation on young people and the mechanisms by which

113 changes occur (Holt \& Jones, 2008). These kinds of youth re-engagement programmes represent a

114 changing viewpoint regarding adolescent development that, as Holt (2008) notes, has occurred over the

115 last decade or so and has come to be labelled 'positive youth development' (PYD). PYD is defined as a

116 constructive approach to young people’s development through the period of adolescence, focusing on

117 the talents, strengths and potential of each individual. As Lerner et al., (2005) have noted, this is a

118 strength-based and broad conception of youth development, which is in contrast to the more traditional

119 deficit-reduction approaches. Damon (2004) concurs:

120 This new approach envisions young people as resources rather than as problems for society.

121 The positive youth development perspective emphasizes the manifest potentialities rather than

122 the supposed incapacities of young people - including young people from the most

123 disadvantaged backgrounds and those with the most troubled histories (p.15). 
Running head: PYD, physical activity interventions and sustained impact

124 The programmes reported in this paper took a very broad approach to positive impact and the term

125 'positive youth development' seems to capture not only that scope but also the key focus on young

126 people’s potential to both engage and develop.

127 There is strong support in the literature for the potential of sport/physical activity to facilitate

128 positive youth development, but historically there has been a lack of robust, empirical data to support

129 claims to effectiveness (see, for example, Morris et al., 2003). More recently, however, there is an

130 emerging body of evaluation research that is providing evidence of both immediate positive impact

131 and, in some cases, sustained impact (e.g. Crabbe, 2006b; Sandford, Armour \& Duncombe, 2008).

132 Moreover, knowledge is accumulating concerning the ways in which future initiatives should be

133 designed in order to maximise the potential benefits for young people and facilitate the sustainability of

134 positive impact (e.g. Sandford, Duncombe \& Armour, 2008). In particular, it is now widely agreed that

135 a key element in effecting positive behavioural change is developing programmes and interventions

136 that have an explicit focus on personal development by promoting positive relationships between

137 participants (Ennis et al., 1999; Crabbe, 2006a; Hellison, Martinek \& Walsh, 2008; Holt \& Sehn, 2008;

138 Petitpas, Cornelius \& Van Raalte, 2008).

139 Despite the emerging evidence, questions remain about the precise mechanisms by which positive

140 youth development can be facilitated through sport/physical activity programmes. Researchers agree

141 that further systematic, longitudinal evaluation research is needed in order to shed light on these

142 mechanisms and processes (e.g. Long \& Sanderson, 2001; Sandford, Armour \& Warmington, 2006). In

143 providing research evidence from the evaluation of two UK-based programmes intended to promote

144 positive youth development through physical activities, and drawing out common themes, it is hoped

145 that this paper can go some way toward addressing these questions. In the next section, key design

146 features of the two programmes are summarised and this provides important contextual information for

147 the development of the evaluation research strategy. 
Running head: PYD, physical activity interventions and sustained impact

150 The data considered in this paper are from the evaluation of two corporate-sponsored initiatives that

151 aimed to use physical activity to re-engage disaffected or disengaged young people in education. The

152 programmes were the HSBC/Outward Bound (HSBC/OB) project and the Sky Sports Living For Sport 153 (SSLfS) programme.

The HSBC/OB project ran for five years between September 2003 and August 2008. Based on

155 a partnership between HSBC in the Community ${ }^{\mathrm{ii}}$, the Outward Bound Trust ${ }^{\mathrm{iii}}$, and five schools local to

156 HSBC's UK head office in the Docklands areas of London; it comprised fully-funded, partially

157 residential outdoor/adventurous activity experiences for pupils deemed by their teachers to be

158 disaffected, disadvantaged or disengaged. In each of the five years of the programme, a cohort of 30

159 young people from year 9 in each school (ages 13-14 years) were selected to undertake a year-long

160 programme of structured outdoor activities (150 pupils in total each year). These activity sessions were

161 designed (by the Outward Bound Trust) to provide individual and group challenges and to develop

162 skills such as team building, communication, and responsibility. Moreover, the sessions were intended 163 to scale progressively, providing more challenging experiences for a smaller number of pupils as they

164 moved through the programme year and affording increased opportunities for these individuals to take 165 responsibility for themselves and others. In addition, a central element of the programme was that each 166 year, a number of HSBC staff volunteered to be involved as mentors, and were trained (by youth 167 workers from one of the programme schools) to work with schools and pupils both within the 168 programme sessions and in follow-up activities within the schools.

169 Each programme year began with an introductory activity day for all pupils during which

170 participants were given the opportunity to meet each other and engage in some basic team-building and

171 sports activities. This was then followed by three residential activity sessions: a week-long event at one

172 of Outward Bound's UK centres; a four-day event at an activity centre close to London; and, for 10

173 pupils perceived to have 'gained the most' from the program, a three-week intensive course at Outward

174 Bound's Ullswater centre in the Lake District. Pupils engaged in activities such as rock climbing, gorge 
Running head: PYD, physical activity interventions and sustained impact

175 walking, high ropes courses, caving, sailing, hiking and rafting. The year concluded with an activity

176 day for all pupils and a celebration/award event held at HSBC’s head office in London.

The Sky Sports Living For Sport (SSLfS) programme is an ongoing national initiative

178 (commenced September 2003) within the UK that encourages schools to design and run school-led

179 projects within a broad framework developed by the programme sponsors (Sky Sports ${ }^{\mathrm{iv}}$ ) and organisers

180 (the Youth Sport Trust ${ }^{\mathrm{v}}$ ). The core aim of the programme is to identify pupils who are having problems

181 with one or more aspect of their school life (e.g. with behaviour, attendance, confidence, being

182 bullied/bullies) and to facilitate their re-engagement in education through participation in physical

183 activities. The initiative is intended to be flexible, and teachers organising SSLfS projects within their

184 schools can select any activity, or combination of activities for their pupil group. Indeed, teachers are

185 encouraged to work with pupils in the selection of activities, and in setting individual and group goals.

186 The list of activities that has been undertaken within SSLfS programmes is extensive, including

187 traditional sports and games (e.g. football, basketball, badminton, swimming and hockey) as well as

188 recreational activities less common to the PE curriculum (e.g. yoga, ultimate frisbee, street dance, free-

189 running and skateboarding) and outdoor/adventurous activities (e.g. rock-climbing, orienteering,

190 canoeing, sailing and rope courses). SSLfS programmes can last from one term to one academic year

191 and group sizes vary from school to school, although groups of 8-16 pupils are most common. Each

192 SSLfS programme culminates in a sport event (often a tournament or competition organised by the

193 project pupils), and completion of the 'course' is marked by some form of celebration event (e.g. an

194 awards evening, an out of school visit or a group meal).

195 Despite their obvious differences, the two programmes shared key design features that governed

196 the choice of feasible research methods, and led the evaluation team to adopt almost identical

197 evaluation strategies within a common evaluation framework. Anderson (2004) notes the proliferation

198 of foundation and charitable organisations that seek to develop community based social programs to

199 meet their missions, commenting that 'These initiatives often have ambitious goals, and so planning

200 specific on-the-ground strategies to meet those goals is difficult' (p. 2). Similarly, Shiner et al., (2004) 
Running head: PYD, physical activity interventions and sustained impact

201 argue that youth social engagement/re-engagement programmes are notoriously difficult to evaluate

202 because sponsors have not thought through why or how an intervention would work, and with whom

203 under what conditions. Indeed, Rossi, Lipsey \& Freeman (2005) argue that before even attempting an

204 evaluation of programme impact, researchers should check whether the program objectives are

205 'sufficiently well articulated' (p. 23) to make it possible to evaluate impact. The two programmes

206 reported in this paper offer an illustration of these methodological issues and challenges.

\section{Evaluation Framework}

208 Rossi, Lipsey \& Freeman (2005) recognise the 'continually changing decision-making milieu of social 209 programs' (p. 22) as a key challenge for evaluators. They argue that researcher flexibility is a key

210 requirement because 'Social programs are not research laboratories... evaluators must expect to be

211 buffeted about by forces and events beyond their control' (p.23). As was noted above, one of the most

212 attractive features of both programmes was the flexibility they offered schools and teachers in selecting

213 pupils and tailoring programme activities to meet their needs. In other words, professional judgement

214 was the key factor determining which pupils should be involved in the programmes. This flexibility,

215 however, also constituted the major challenge facing the evaluation team, and it resulted in the design

216 of a multi-layered evaluation strategy using qualitative research methods built largely around individual

217 pupil profiling. Between 2003 and 2007 (years 1 to 4 of each programme), over 10,000 young people

218 participated in either the HSBC/OB project or SSLfS programme. Impact data have been collected on

219 over 50\% of all SSLfS pupils engaged in the programme nationally ( $\mathrm{n} \sim 4700$ ) and 90\% of HSBC/OB

220 pupils from the five participating schools $(\mathrm{n} \sim 540)$. In the next sections, details on the design, methods

221 and participants are explained and are also summarised in tables for clarity (Tables 1 and 2).

\section{Evaluation Design and Rationale}

House (2005) points out that although there has been a growing faith in large scale evaluations

224 using only experimental methods, these have rarely delivered what they promise. Instead, he suggests

225 evaluation studies should be 'methodologically ecumenical' and that they often need to adopt a

226 different concept of causation: 
Running head: PYD, physical activity interventions and sustained impact

Social causation is more complex than regularity theory suggests. Even with the same program, there are different teachers at different sites who produce different results. We might try to control for the teachers, but there are so many variables that might influence the outcomes, the researchers cannot control for all of them.

231 This certainly seems to reflect the problems faced in these two evaluation projects. House also argues

232 that programme theory can be a useful approach to the evaluation of social programmes, and that there 233 is a need for theories that are applicable to individual programmes, rather than seeking grand social 234 theories. In similar vein, Rossi, Lipsey \& Freeman (2005) point out that 'conducting social research at 235 a high scientific standard generally requires resources that exceed what is available for evaluation 236 projects' (p.24) and that was certainly a problem in these evaluation projects. Rossi et al. also argue 237 that such issues do not mean researchers can 'blithely dismiss scientific concerns in evaluation' (p. 25) 238 and it was the need to do credible, defensible research that led to the eventual evaluation design in this 239 case. Thus, the three dimensional evaluation of the HSBC/OB and SSLfS programmes centred on 240 individual pupil profiling, school-level case studies and the creation of programme Logic Models.

241 There are many respects in which this design strategy can be criticised, and it was certainly labour 242 intensive. On the other hand, as other evaluators have found, compromises are often required in the 243 evaluation of complex social programmes.

244 Pupil profiling: the purpose of the pupil profiles was to capture information on teachers'

245 professional judgements in order to create a baseline profile on each pupil, and to record progress from 246 that profile. Thus, teachers were asked to record reasons for pupil selection and to support their reasons 247 with 'hard' school data (e.g. absenteeism statistics; behaviour reports) where they were applicable and 248 available. Teachers were then prompted to report on pupil progress from the baseline immediately after 249 the programme (positive, negative or no change from baseline) to determine 'distance travelled' 250 (Crabbe, 2005b). In the case of the HSBC/OB project, updates were also requested half way through 251 the project year. They were further prompted at 12, 24 and 36 months after programme completion to 
Running head: PYD, physical activity interventions and sustained impact

252 determine whether any changes recorded immediately after engagement in the programme were 253 maintained.

254 Case studies: in addition, collective case studies (Stake, 2005) were conducted in each 255 evaluation project at the school level to supplement the data from pupil profiles (Yin, 1984). The main 256 research activities in these case studies were observation of programme activities, interviews with key 257 adults and youth participants, focus group discussions, open-ended surveys, semi-structured reflective 258 journals, and structured feedback sheets (e.g. Oliver \& Lalik, 2001; Clark \& Moss, 2001; Harper, 259 2002).

Logic Models: models were developed for each programme to identify the ways in which the

261 programme sponsors sought to achieve their aims through the programme activities. (Kellogg

262 Foundation, 2001). 'Logic models’ can clarify and make explicit foundational features of a programme, 263 and can provide a useful communication framework for evaluators and sponsors, especially where aims 264 are rather nebulous and the paths to outcomes unclear: The program logic model is defined as a picture of how your organization does its workthe theory and assumptions underlying the program. A program logic model links outcomes (both short- and long-term) with program activities/processes and the theoretical assumptions/principles of the program (p.iii).

269 An example of an early Logic Model for the HSBC programme is provided in Appendix A. Finally, mindful of the need to assure the quality of the qualitative research design the

271 evaluators adopted a framework developed by the National Centre for Social Research (Spencer et al.,, 272 2003) that focuses on the outputs of qualitative inquiry and helps consumers of the research to make 273 judgements about its quality. In evaluation reports to the sponsors, therefore, checklists were provided 274 drawing upon the appraisal questions and quality indictors in the framework, including indicators on 275 research design, ethics, data analysis and reporting findings.

\section{Data Collection}


Running head: PYD, physical activity interventions and sustained impact

277 This paper draws upon data from interviews, focus groups, journals and individual pupil profiles

278 generated by teachers, mentors and pupil participants. Reference is made in the discussion to the use of

279 Logic Models. The data collection process was similar in each programme, although the lower pupil

280 numbers on the HSBC/OB programme, and the sustained relationship with five schools, facilitated

281 greater depth. The higher number of schools and pupils involved in the SSLfS project resulted in some

282 adaptation to data collection in order to manage the volume of data. In each section below, a table

283 summarising the research undertaken is followed by a more detailed explanation of data collection

284 procedures/features and an indication of where further information on each individual programme can 285 be found.

287 HSBC/OB:

288 [INSERT TABLE 1]

289 - At the beginning of the programme, individual pupil baseline profiles were generated for each 290 pupil using teachers’ professional judgements via open-ended surveys. 400 full profiles were 291 collected over 4 years. Teachers were asked to give their reasons for pupil selection and any 292 illustrative examples or data to support their selection;

293 - Update profiles were collected at intervals after the first main programme activity (6, 12, 24 294 and 36 months) again using an open-ended survey. Teachers were asked to comment on each pupil’s current status as well as indicate the direction of any perceived change from the baseline level (i.e. positive, no change or negative);

- The five partner schools were also evaluated as case studies in each year. In each case, data were collected through observations of project activities, interviews with lead teachers and, where possible, senior management staff and focus groups with participating pupils. The evaluators were also invited to programme steering meetings, which facilitated regular contact with the teachers and sponsors; 
Running head: PYD, physical activity interventions and sustained impact

- Data from pupils on project involvement and any perceived benefits were also generated via pupil journals, open-ended surveys and focus group discussions.

304 For further information on this programme and its evaluation see Armour \& Sandford (2004, 2008),

305 Sandford, Armour \& Duncombe (2008) and Sandford, Duncombe \& Armour (2008).

307 SSLfS:

308 [INSERT TABLE 2]

309 - In year one of the programme, individual pupil baseline profiles were generated for each pupil using teachers’ professional judgements via open-ended surveys. Teachers were asked to give reasons for pupil selection and provide any available supporting school data (e.g. attendance or behaviour records). In subsequent years, data from the year one responses were used to create a list of potential reasons for selection, making data collection and analysis easier. Teachers were offered space to include additional reasons or comments. Where no supporting data for selection were available, teachers were asked to use a 5 point professional judgement rating scale to identify a pupil's starting point. This was a compromise measure to account for the fact that most reasons for selection could not be supported by 'hard' data (i.e. the pupil was ‘withdrawn’; struggled to make friends; lacked confidence etc).

- Update profiles were collected at the end of the project. Where no 'hard' data had been provided at the outset, teachers were still able to update their professional judgement rating scale.

- Up to 20 school-level case studies were undertaken in each project year. New case study schools were selected each year to ensure geographical spread, range of school types and project activities, and to focus on emerging issues. In year four, 18 sustainability case studies were also undertaken. In each case, data were collected through the observation of project activities, interviews with key teaching staff, and interviews or focus groups with participating pupils. 
Running head: PYD, physical activity interventions and sustained impact

- A sustainability of impact survey was undertaken in years 2, 3 and 4 of the project, and was disseminated to all schools who had participated in previous years. For pupils who were recorded as showing positive impact immediately after the project, teachers were asked to comment whether or not, based on their knowledge of the pupils, they had maintained this improvement since project completion (i.e. periods ranging from 12, 24 and 36 months). Teachers were also asked to comment on the reasons for any sustained improvements.

334 Further information on this programme and its evaluation can be found in Armour et al., (2007), 335 Sandford, Armour \& Duncombe (2008) and Sandford, Duncombe \& Armour (2008).

\section{Data Analysis}

As was noted earlier, the Logic Models were used to ensure clarity and a shared understanding

339 between the programme sponsors and the evaluators about the ways in which the programme activities 340 were designed to meet the programme aims. The data from pupil profiles were analysed using 341 descriptive statistics (i.e. the frequency of a particular response or the percentage of the total data set

342 that this represented). The different project structures resulted in some differences in analysis. In

343 HSBC, individual pupil profile data were summarised to show the number and percentage of pupils

344 who had improved from, maintained, or dropped below their baseline profiles at 6, 12, 24 and 36

345 months following the commencement of project activities. It was these latter updates that provided the 346 sustainability data.

347 In the SSLfS project, the data from pupil profiles were analysed according to the area of 348 improvement identified by teachers (behaviour, attendance and self-esteem). Data were collated and a 349 mean was calculated for the baseline period and compared with that for the project period. This method 350 of analysis was used for teachers' data in the case of both professional judgements, in the form of rating 351 scales, and where specific school statistics were available, for example attendance rates or number of 352 behaviour referrals. Interestingly, the findings were almost identical whether either measure was used. 353 Data from the sustainability of impact survey were collated to indicate the number of pupils who 
Running head: PYD, physical activity interventions and sustained impact

354 showed an improvement immediately after project completion, and who were perceived by teachers to 355 have maintained this improvement in subsequent years.

Data from the school case study visits for each programme (which took the form of fieldnotes,

357 interview transcripts and written feedback responses) required a more detailed qualitative analysis.

358 These data were collated and then analysed thematically, using an approach similar to the constructivist 359 grounded theory outlined by Charmaz (2000). Unlike more traditional, structured versions of grounded 360 theory (Glaser \& Strauss, 1967; Strauss \& Corbin, 1998), this approach facilitated active coding and 361 offered the opportunity to focus on participants' thoughts and feelings, and to identify differences. 362 Thus, themes were constructed, in part, around responses on core project aims or issues of interest 363 generated through discussions with project participants (teachers, pupils, sponsors etc.). There was also 364 the opportunity for new themes to be identified and explored. A worked example of the data analysis 365 processes can be seen in Appendix B.

\section{$366 \quad$ Limitations in Evaluation Design}

As was noted earlier, the authors acknowledge a number of limitations to the evaluation design.

368 Similar to the experiences of other evaluators, it was found that both programmes had been designed 369 and were underway before the evaluators were commissioned (which explains the need to generate 370 Logic Models to clarify designs and aims). In addition, the programme aims were very broad, seeking

371 high and lasting impacts on large numbers of young people; the research budget was low in the context 372 of the extensive scope of the aims; there was no standardisation in the selection procedures for the 373 youth participants; teachers/staff had considerable flexibility at each stage of the programmes (which 374 was a key attraction for participating schools); there was no possibility to establish a meaningful 375 control group; and there were high sponsor expectations for meaningful data within tight reporting 376 deadlines (DfEE, 2000; Burton, 2006). Indeed, it is worth noting that, as they worked with schools over 377 time, the sponsors came to understand school needs better. This resulted in a conundrum: the 378 programmes were made more flexible and responsive to meet the needs of teachers and schools which, 379 in turn, made it increasingly difficult for the evaluators to provide robust evidence of impact. 
Running head: PYD, physical activity interventions and sustained impact

Given these limitations, it could be argued that robust evaluation was impossible. On the other

381 hand, the evaluators had the opportunity to design a research methodology that could attempt to

382 accommodate the flexibility inherent in the programmes, the variability inherent in the different schools

383 involved and the limited time teachers were able to dedicate to research. In addition, the longitudinal

384 funding facilitated data collection on large numbers of pupils that could be sustained over four years.

\section{Findings}

386 Although there are variations in the data from the HSBC/OB and SSLfS projects, the broad findings

387 regarding the nature of programme impact are remarkably similar. A discussion of the findings on 388 impact more broadly has been reported elsewhere (see Sandford, Duncombe \& Armour, 2008). The 389 focus of this paper will be upon the factors identified by programme participants (teachers, mentors and 390 pupils) as contributing to the sustainability of impact. This can, therefore, make a contribution to the 391 knowledge base on programme design features and processes that are most likely to lead to sustained 392 positive impact from physical activity interventions. In the first section below, the findings from the 393 pupil profiling process are reported, followed in the second section by explanatory findings from the 394 school case studies.

\section{Sustained Impact: The pupil profiles}

396 As might be anticipated, collecting data on sustained impact over a period of time is challenging given 397 that pupils are no longer centrally involved in programme activities. Moreover, there is likely to be 398 little information on what other activities pupils have engaged in since programme completion for, as is 399 often the case, research funding ends with the end of the programme. This might explain the lack of 400 robust data on sustainability in such youth development programmes. As has been explained above, the 401 evaluation projects reported here were structured to (partially) overcome these limitations. Data 402 collection centred on the initial reasons teachers provided for pupil selection for the programmes, and 403 both initial and sustainability data updates were similarly focussed. In effect, this was the only element 404 of the programmes that had any consistency over time. 
Running head: PYD, physical activity interventions and sustained impact

Although there were challenges in collecting sustainability data from schools, and the findings

406 should be read with caution, they are also interesting. For example, in year 2 of the SSLfS project

407 (2004-2005) teachers provided sustainability data for 67 pupils who had shown an initial improvement 408 from their baseline profiles. Of these, 94\% were perceived to have maintained those improvements for 40912 months. Similarly, in year 3 of the evaluation (2005-2006), 43 schools provided sustainability data 410 on 312 pupils, with approximately 90\% maintaining positive improvements for 12 months. In year 4, 41144 schools provided data on pupils who had demonstrated improvements and, similar to the findings

412 from the previous year, approximately 90\% of these maintained those improvements for 12 and 24

413 months (see table 3). One school also provided data on 7 pupils who had completed the programme 36 414 months previously and it is interesting to note that the lead teacher believed that all of these pupils had 415 sustained their improvements for 3 years.

416 The sustainability data from the HSBC/OB project also indicate that many, although not all, 417 pupils maintained positive improvements for up to 36 months after programme involvement. Indeed, 418 when the data are combined for all three years, it can be seen that almost $70 \%$ of pupils retained their 419 positive improvements from the teacher-reported baseline at the point of leaving school (at 36 months). 420 This is illustrated in table 4, which shows the combined data for pupils involved in Years 1, 2 and 3 of 421 the HSBC/OB project.

422 [Insert Table 3]

423 [Insert Table 4]

424 The data presented in tables 3 and 4 indicate that, where the SSLfS programme had an initial impact on 425 the young people who participated, this impact was likely to be sustained for 12, 24 (and potentially 426 36) months. Likewise, in the HSBC/OB programme, positive improvements were being maintained by, 427 on average, well over $50 \%$ of pupils up to 24 and 36 months after the programme activities had ended. 428 These findings, then, appear to support the notion that sport/physical activity programmes can have a 429 positive long-term impact upon participants. However, while the pupil profiles provide an indication of 430 impact, the case study data provide important information on the mechanisms most likely to lead to 
Running head: PYD, physical activity interventions and sustained impact

431 sustained impact. As might be expected, these data reveal a complex set of processes leading to the 432 findings.

\section{Sustained Impact: The case studies}

In case studies, teachers/school staff were interviewed to find out what may have helped the

435 young people to maintain positive improvements. A number of similar factors were identified in both

436 programmes and they highlight the significance of social processes around physical activity

437 interventions; indeed, the social aspect of programme involvement was reported as being pivotal. Thus,

438 whereas sport and physical activity were used as a vehicle for both projects, they themselves were not

439 perceived (by teachers) to be as significant in terms of impact on pupils as the opportunities that were

440 provided for social interaction and building positive relationships. Six common themes on the

441 conditions required for sustainable impact resulted from the data analysis process. These six themes are

442 reported individually in the next section, supported by illustrative data from both programmes. As was

443 noted in the introduction, the purpose of the paper is twofold: to identify the themes and to illustrate the

444 complex ways in which they interacted to contribute to sustained impact. The latter purpose is

445 undertaken in the discussion.

446 i. Matching pupils’ specific needs with programme objectives

447 Within both programmes, a common response from teachers was that it was important to select the

448 'right' pupils to participate. Within the SSLfS programme, for example, some teachers suggested that

449 the activities simply did not work if the 'wrong' pupils were chosen or if too many of the pupils had

450 dominant personalities or were very disruptive. Conversely, it was often stated that programmes had

451 been successful when they were designed to be appropriate to the needs of a particular group of pupils:

$452 \quad$ They need to be students that can work together. And they need to be students ideally with

similar issues or certainly with similar aspirations, because otherwise, you tackle activities that some of them don't want to engage in (Lead teacher, SSLfS).

455 Similarly, within the HSBC/OB programme, teachers commented that they considered a number of 456 factors in their selection of pupils, including not only their potential to gain from the experience but 
Running head: PYD, physical activity interventions and sustained impact

457 also their capacity to engage with the process. In this case, the nature of the activities was largely

458 dictated by the structure of the programme, so teachers noted that they had to bear this in mind when

459 identifying their pupil group:

460 I know there are some pupils who would benefit from some kind of programme, but this is 461 not the right one for them (Teacher, HSBC/OB).

462 The first point to note, therefore, is that participant selection was a complex process that relied on 463 teachers’ professional judgments about both the programme and the needs of individual pupils.

464 Like many other professional judgments, the decision-making process seemed to be based on a set 465 of factors rooted in experience and expertise.

466 ii. Locating project activities outside of the 'normal' school context

467 Whilst SSLfS projects varied considerably, with schools being free to select any sport/physical activity 468 they deemed appropriate, the programmes that incorporated off-site or 'new' activities were 469 particularly valued:

I think it was the off-site nature (that) was very important...the opportunity to do a different activity (not) part of the bread and butter of the PE curriculum... it makes the programme more attractive... and ensures that they turn up week after week (Lead teacher, SSLfS).

473 Likewise, the off-site and residential nature of the HSBC/OB programme was identified as a significant

474 feature in terms of engaging and motivating pupils, particularly as the disadvantaged background of 475 many of the selected pupils meant that they had rarely, if ever, been away from home: They (the pupils) rarely travel out of Tower Hamlets (an area of London), very, very rarely. So, you know, going to Wales is a big thing for them... I mean, some of them have never seen the sea before (Teacher, HSBC/OB).

479 In both cases, the suggestion from teachers was that taking pupils out of the school context helped them 480 in a number of ways; e.g. by increasing the perceived importance of the programme, engaging their 481 interest, raising the scale of the challenge or by distancing them from aspects of the school environment 482 that were contributing to their personal difficulties. 
Running head: PYD, physical activity interventions and sustained impact

483 iii. Working closely with pupils to choose activities, set targets and review progress

484 The importance of giving young people a sense of belonging and ownership in programmes aimed at

485 promoting positive youth development, and, in particular, of involving them in key decisions relating to

486 their participation is widely reported. These sentiments were echoed by teachers from both HSBC/OB

487 and SSLfS. For example, a number of SSLfS activities incorporated time for planning, reviewing and

488 setting targets with pupils. There were examples where teachers would set targets, which the pupils had

489 to achieve in order to be allowed to participate in activities the next week. Furthermore, teachers felt

490 that giving ownership of the programme to young people was important:

491

The pupils loved planning and taking part in activities of their choice (Lead teacher,

492 SSLfS).

493 Within the framework of the HSBC/OB programme, pupils were not able to be involved in planning

494 the main activities, but in the residential Outward Bound sessions there was a strong focus on pupils

495 taking responsibility for themselves and their group (e.g. in terms of arriving for activities on time and 496 with the appropriate equipment). Moreover, at the end of each day, pupils were asked to reflect on their

497 achievements and consider their goals for the following day by recording them in a personal journal.

498 Teachers commented that they felt this had been valuable for the pupils:

$499 \quad$ I loved the way that they summarised what they'd done every evening, they had a focus for

$500 \quad$ the day, and their mentors were reinforcing that as well as instructors (Teacher,

$501 \quad H S B C / O B)$

502 In each case, involving pupils in the planning and review of programme activities was perceived to add

503 a great deal to the experience and to contribute to the degree of positive impact.

504 iv. Establishing positive relationships between programme leaders, mentors and pupils

505 The importance of the role of an adult 'mentor' has been stressed in numerous contexts. This was also 506 identified strongly by the different groups of participants involved in both programmes. For example,

507 both teachers and mentors commented that working closely with pupils had helped to establish good

508 relationships and contribute to the pupils' development: 
Running head: PYD, physical activity interventions and sustained impact

One of my students said, 'Mrs Smith has changed my life'. This was completely out of the blue... I am not in this job to receive pats on the back, but I was very touched by this spontaneous remark from a student with Aspergers (Teacher, SSLfS). with other adults (e.g. mentors)... it enables them to see the human side of adults, and enables them to engage with the adults on an 'adult' level, rather than just as authority figures (Mentor, $\mathrm{HSBC} / \mathrm{OB})$.

517 In addition, pupils indicated that they had enjoyed working with teachers and mentors, and had 518 appreciated being able to get to know them as people rather than just as the aforementioned 'authority 519 figures’. For example: that, they became our friends (Pupil, HSBC/OB).

522 Whilst the role of the teacher or mentor was clearly important, however, data from the research projects

523 also identified that strong relationships between participating pupils is also a factor that may lead to 524 sustained improvements:

They used to talk in the mini bus about things they had done, and have a little sing song on the way home, and just things that they normally wouldn't experience because they

528 In addition, it was also noted that, whilst support from adults during the project was important, 529 continued support was essential in helping young people to maintain improvements:

530 I think it is down to maintaining the contact, maintaining the links, by not disappearing. At 531 the end of the project, we didn't disappear, we were still there so the relations that we built 532 up could carry on (Lead teacher, SSLfS). 
Running head: PYD, physical activity interventions and sustained impact

It's actually an issue, what is our role of 'mentor' going forward? I think there is more to it than just being there as another aide to make sure that the activities happen... you've got to keep contact with the young people (Mentor, HSBC/OB).

One thing... is this longevity thing, and that is very important, in fact if you didn't continue it's worse than if you didn't start in the first place because you get to the point where there is an alliance and there is a relationship and if that suddenly disappears from both sides there is going to be a potential vacuum after this (mentor, HSBC/OB).

542 The key point to be noted from this finding, therefore, is the multiple levels on which the 543 development of positive relationships is desirable. This has clear implications for programme 544 design (and cost).

545 v. Giving pupils the opportunity to work with (and for) others

546 A large proportion of pupils were selected to participate in both the HSBC/OB and SSLfS programmes

547 because of poor social skills, poor communication skills or perceptions of low confidence. It is,

548 perhaps, unsurprising, therefore, to find that many teachers stressed the importance of providing

549 opportunities for pupils to work collaboratively. The physical activity setting offered good 550 opportunities for this aspect:

$551 \quad$ They are brilliant now. It's just because everything we've done has been based on 552 teamwork. Because there's only 8 of them, they've had to co-operate, they've had to work $553 \quad$ together and they are doing it really well (Lead teacher, SSLfS). (Abdul) is probably the greatest success story from our school. He was previously shy, underachieving and on the receiving end of some bullying. Now he's confident, achieving above expectations and developing some very good social skills (Teacher, HSBC/OB). 
Running head: PYD, physical activity interventions and sustained impact

It's been good for them to meet people they wouldn't normally mix with I think. You could see them eyeing each other up on the first activity day, but I think some of them are really good friends now and they've learnt from each other, you know being from different backgrounds and things (Mentor, HSBC/OB).

564 The pupils also acknowledged this and appreciated the chance to work with each other, and with groups 565 of other young people with whom they did not normally interact:

566 ...the fact that I've never worked with special needs children, it was a first for me and I could do it (Pupil, SSLfS).

568 Moreover, teachers within the HSBC/OB programme also noted that working with pupils from other 569 schools was important in helping young people meet others from different cultures and backgrounds: 570 It has been really good to work with the other schools, particularly as this is a boys' school 571 with a predominantly Bangladeshi population. They have learnt a lot from being in mixed groups, especially with the girls. It was so far removed from their day to day experience in school (Teacher, HSBC/OB).

574 These comments highlight, once again, the significance of social interaction within these youth 575 development programmes, and reinforce findings from within the sport/physical activity literature that 576 highlight this as an essential factor in bringing about positive and sustained impact.

577 vi. Structured pathways to enable sustained involvement in programme activities or complementary $578 \quad \underline{\text { activities }}$

579 One of the key points raised by teachers in both programmes was the need to give thought to what 580 would happen to the young people once the activities had ended. This reflects concerns that have been 581 raised in the literature over the short-lived nature of initiatives targeting disaffected or disadvantaged 582 youth. In both programmes, teachers commented that, in order to maintain positive impact, it was 583 important to establish alternative ‘pathways’ for pupils once programme activities had ended. For 584 example: 
Running head: PYD, physical activity interventions and sustained impact

585

586

587

588

589

590

591

592

593

594

595

596

597 Findings from the HSBC/OB project also indicate that the young people who progressed to the later 598 stages of the programme (i.e. were selected for weekend residential and three-week residential events)

599 were more likely to maintain an improvement from baseline than those who did not. Moreover,

600 teachers noted that pupils who sustained their positive development after completing their activity year 601 were those who went on to engage in alternative programmes, initiatives or activities e.g. the Duke of

602 Edinburgh Award Scheme, Young Enterprise and business mentoring schemes ${ }^{\mathrm{vi}}$. It was noted that these 603 activities allowed pupils to transfer the skills learnt through their programme involvement (e.g.

604 teamwork, communication and leadership skills) to alternative situations, and to develop them further, 605 and that this allowed for their continued development. In the next section, these six themes are 606 considered both in combination and in the context of the wider literature.

607 608

609 Recognising both the strengths and the limitations of the evaluation research design, it can be argued 610 that the findings reported above can make a contribution to the existing research. Individually, the six 
Running head: PYD, physical activity interventions and sustained impact

611 mechanisms identified as leading to successful programmes in these two evaluations echo some of the

612 findings from previous research (see Hellison, 1995; Ennis 1999; Donnelly \& Coakley, 2002; Sandford

613 et al., 2006). However, developing an understanding of how they worked in combination, and taking

614 into account the detail and duration of data collection, it is possible to see ways in which these findings

615 provide important insights into the sheer scale of pre-planning that is required in sport/physical activity

616 programmes to maximise the potential benefits for disengaged/disaffected young people.

617 It should come as no surprise to find that allowing teachers to match pupils' specific needs with

618 the programme objectives was an important factor in programme success. This is endorsed within the

619 existing sport/physical activity literature (DfES, 2004; Sandford, Armour \& Warmington, 2006). In

620 these programmes, teachers were given the freedom to appraise the activity on offer and to select pupils

621 they felt would 'benefit'. Thus, teachers were able to take into account the proposed activity, any key

622 local contextual factors, and a range of pupil needs. The teachers were also involved in the programme

623 activities with the pupils, and this was clearly a key factor in their success. Coote, Allen \& Woodhead

624 (2004) have argued that evaluators should make greater efforts to learn from the knowledge and

625 experience of practitioners, and that methods should be found to achieve this. Certainly, in this

626 evaluation there appeared to be few other options available.

627 Yet, the first theme is clearly and intricately linked to the second: locating project activities

628 outside of the 'normal' school context. Donnelly and Coakley (2002) argued that programmes aimed at 629 promoting social inclusion must provide ‘safe spaces’ for participants, and Peacock (2006) noted that

630 evaluations of out-of-classroom learning confirm such an approach can promote positive attitudes,

631 arouse interest and improve behaviour. It has also been noted, however, that positive learning outcomes 632 outside of the classroom are not a 'given' and that there is a need for teachers/educators to 'consistently 633 aid students to understand how what they experience in the outdoor classroom connects to, extends, 634 and reinforces their in-school work’ (Dillon, Morris, Rickinson \& Scott, 2005, p.5). In these two 635 programmes, lead teachers were involved with the pupils throughout the programme activities, thus 
Running head: PYD, physical activity interventions and sustained impact

636 they were able to ensure the learning environment was appropriate, and could make links to the in637 school context.

638 The third theme - working closely with pupils to choose activities, set targets and review 639 progress - is widely endorsed in the PYD literature. For example, Donnelly \& Coakley (2002) and 640 Riley \& Rustique-Forrester (2002) have argued for the importance of giving young people a sense of 641 belonging and ownership in such programmes and, in particular, of involving them in key decisions 642 relating to their participation. In many ways the SSLfS programme was a model in this respect, given 643 that each year, participating groups were able to select activities and, as long as they were feasible, they 644 could be undertaken by young people. The funding provided by sponsors in this programme was not 645 extensive, but it did facilitate unusual and off-site activities making the participant group feel 'special'. 646 This is also one of the reasons why, over time, the selection criteria for this programme broadened 647 beyond pupils who had disruptive behaviour issues to include pupils who had other forms of perceived 648 need, based on disadvantage or more passive forms of disaffection.

The fourth theme, establishing positive relationships between leaders, mentors and pupils, was a 650 key feature of both programmes although it operated in slightly different ways in each. The importance 651 of the role of an adult 'mentor' has been stressed in numerous contexts within the physical education, 652 informal education and mentoring literature (e.g. Martinek \& Hellison, 1997; Richardson \& Wolfe, 653 2001; Reid, 2002) and it has been suggested that having someone to turn to who is more than 'just' a 654 teacher is important for some young people (Bennetts, 2003; Vulliamy \& Webb, 2003). In the 655 HSBC/OB programme, one of the key features was the training of adult mentors from within HSBC 656 staff to work with young people on programme activities. Although this was not always a 657 straightforward process, some of the mentors became fully involved and acted as mentors for several 658 years. In these cases, the feedback from pupils suggests this was one highlight of the whole 659 programme. This mirrors findings from the physical education and mentoring literature that identifies 660 the importance of building sustained relationships between adult leaders and young people (e.g. 661 Golden, Lines \& Sims, 2002). In the SSLfS programme, however, lead teachers (usually physical 
Running head: PYD, physical activity interventions and sustained impact

662 education teachers) were most closely involved with pupils over time. The programme activities

663 offered teachers the opportunity to work with a small group of pupils in a sustained way in an unusual

664 learning context and this, too, offered important opportunities to develop positive adult/young people 665 relationships.

In addition to developing positive relationships with adults, these programmes offered young

667 people the opportunity to work with and for other young people (theme five). Martinek and Hellison

668 (1997) have argued that 'the nature of physical activity - active, interactive, highly emotional -

669 certainly provides the possibility of exploring and practising values, teamwork, goal-setting, peer-

670 teaching, conflict resolution, and so on’ (p.44). In addition, Crabbe (2006a); Petitpas et al., 2008 and

671 Coalter (2000) have all highlighted the importance of wider personal and social development goals in

672 sport/physical activity programmes. In both programmes, social interaction was a key feature,

673 including offering young people the opportunity to work with younger pupils (SSLfS) and to interact

674 with pupils from different schools (at the OB centre and post-activity celebration events in HSBC/OB).

675 However, this feature on its own would have been less successful in these programmes had other

676 features not been in place; for example, appropriate selection of pupils, an unusual but 'safe' context

677 for activities and positive relationships with the key adults.

678 The sixth feature that contributed to the reported success of these programmes was the

679 availability of structured pathways to enable young people to have sustained involvement in further

680 project or complementary activities. Concerns have been raised in the existing youth disaffection

681 literature about the short-lived nature of initiatives targeting disaffected or disadvantaged youth (e.g.

682 France, 2007; Morris et al., 2003; Long \& Sanderson, 2001). There have also been calls for multi-

683 agency approaches to tackling disaffection and promoting positive youth development, and for better

684 collaborations between key institutions, organisations and agencies (Steer, 2000; DfES, 2003c). What

685 can be learnt from these two programmes, however, is that for such strategies to be effective, schools

686 and teachers must be fully engaged in programme activities which, in turn, must be embedded in

687 schools in an appropriate way. This ensures that where young people develop potential interests as a 
Running head: PYD, physical activity interventions and sustained impact

688 result of programme participation, an adult based at - or connected to - the school is available to

689 recognise that interest and nourish it by highlighting further opportunities. It should be remembered 690 that any positive impact seen immediately after relatively short interventions is likely to be tentative, 691 particularly where a young person has to contend with considerable personal problems or issues.

693 an example), the challenges inherent in linking the activities to the programme aims became apparent.

694 Sharing these models with the sponsors and in, the case of HSBC/OB, the lead teachers, led to

695 productive discussions about the ambitious nature of the aims, and provided an opportunity for teachers

696 to express their concerns that the aims were unrealistic. This, in turn, led to a more productive dialogue

697 between the HSBC/OB sponsors and the lead teachers. The sponsors reiterated that the programme was

698 essentially a philanthropic activity that sought to give young people a chance in life, aid their personal

699 and social development and encourage them to engage in education. Moreover, the teachers were

700 perceived as being actively engaged in the project as partners from whom the sponsors could learn. In

701 many ways, this was an ideal approach from which other sponsors and funders could learn.

\section{Conclusion}

704 As was noted at the beginning of this paper, there is a strong belief in the potential for physical 705 activity/sport participation to bring about positive benefits for young people. Certainly, within the UK, 706 a raft of recent policies/strategies ${ }^{\text {vii }}$ can be seen as evidence of a prevailing faith in the ability of 707 physical activity, sport and, indeed, physical education, to contribute positively to young people’s 708 positive personal development and facilitate social inclusion (DCSF, 2005; DCMS, 2007; Sandford, 709 Duncombe \& Armour, 2008). Moreover, the awarding of the 2012 Olympic Games to London has 710 added weight to such beliefs and is at the heart of expectations that a broad youth legacy (physical, 711 social and economic) can be achieved through structured physical activity/sport interventions (DfES, 712 2005; Sandford, Armour \& Duncombe, 2010). 
Running head: PYD, physical activity interventions and sustained impact

Despite strong convictions regarding the potential of physical activity/sport participation to reap

714 benefits for young people, there has, however, been a relative lack of detailed information regarding the

715 mechanisms by which physical activity/sport interventions lead to positive outcomes (Coalter, 2000;

716 Bailey, 2005; Sandford et al., 2006). The data reported in this paper offer some interesting insights into

717 these mechanisms but, more importantly, into the complex ways in which they interact to maximise the

718 potential of sport/physical activity interventions.

The limitations of the data reported here have been acknowledged. Flexibility, responsiveness

720 and the privileging of the professional judgement of teachers were key attractions for schools and these

721 features contributed to the undoubted successes of these two programmes. At the same time, these key

722 features presented the researchers with some formidable challenges. Nonetheless, through a cautious

723 and realistic evaluation design, the researchers have been able to capture data on large numbers of

724 pupils over a four year period. The pupils engaged in different programmes that had very similar aims,

725 and so it was feasible to employ a common evaluation strategy centred on developing Logic models as

726 a communication tool, and drawing data from individual pupil profiling and school-level case studies.

727 Within its very real limitations, therefore, the data can offer helpful insights into the ways in which six

728 interlinked mechanisms can lead to sustained positive impact from sport/physical activity interventions.

i The PESSCL (Physical Education School Sport Club Links) strategy was launched by the UK government in 2002 and saw significant funding (£459 million) invested in physical education and school sport. The NOPES (New Opportunities for PE and Sport) initiative also saw significant investment (£751 million) in PE and sport, supported by lottery funding. Positive Futures is a national social inclusion project in the UK that uses various activities, including sport, to engage with socially marginalised young people.

ii HSBC in the Community is a sub-group of the global bank HSBC’s corporate social responsibility arm, and has responsibility for promoting positive relationships with the local community.

iii The Outward Bound Trust is a global educational charity that has a long history (over 65 years) of using outdoor experiences and challenges to facilitate young people’s development.

iv Sky Sports is the dominant subscription television sports brand in the United Kingdom and Ireland and is the current sponsor of the 'Living For Sport' programme.

v The Youth Sport Trust was established in 1994 and is an independent charity that has a focus on supporting, encouraging and developing young people through PE and sport.

vi The Duke of Edinburgh's Award is an achievement award for young people, in which they undertake a number of activities intended to promote personal and social development. There are three levels of award (bronze, silver and gold) and each includes physical, social, and community elements. Young Enterprise is a national education charity founded in 
Running head: PYD, physical activity interventions and sustained impact

1963 to forge links between schools and industry, and business mentoring schemes are similar educational initiatives designed to equip pupils with a better understanding of career opportunities and develop their employability skills through regular meetings with volunteer mentors from local businesses.

vii Recent policies/strategies include PESSCL and NOPES (see endnote i), as well as PESSYP (the Physical Education and Sport Strategy for Young People, a successor to PESSCL), Every Child Matters and Youth Matters (for further information see www.dcsf.gov.uk/everychildmatters).

\section{Acknowledgments}

The authors would like to acknowledge that this paper forms part of two recent research projects: the evaluations of the Youth Sport Trust/Sky Sports 'Living For Sport' project and the HSBC Education Trust physical activity programmes. The authors are grateful for the support of these bodies, their continued interest in the evaluation research and their desire to facilitate wider academic learning. 
Running head: PYD, physical activity interventions and sustained impact

\section{References}

730 Anderson, A. A. (2004). Theory of change as a tool for strategic planning. Aspen Institute.

731 http://www.aspeninstitute.org/sites/default/files/content/docs/roundtable\%20on\%20community\%20ch

732 ange/TOC_2004.PDF Accessed 15th June 2010.

733 Bailey, R. (2005). Evaluating the relationship between physical education, sport and social inclusion.

$734 \quad$ Educational Review, 57(1), 71-90.

735 Bailey, R. (2008) Youth sport and social inclusion. In, N. Holt (Ed. ) Positive youth development 736 (pp.85-96). London: Routledge.

737 Bennetts, C. (2003). Mentoring youth: Trend and tradition. British Journal of Guidance and 738 Counselling, 31(1), 63-76.

739 Burt, J.J. (1998). The role of kinesiology in elevating modern society. Quest, 50, 80-95.

740 Charmaz, K. (2000). Grounded theory: Objectivist \& constructionist methods. In N.K Denzin \& Y.S.

741 Lincoln (Eds.), Handbook of qualitative research (2nd Edition) (pp. 509-536). London: Sage.

742 Clark, A. \& Moss, P. (2001) Listening to young children: The mosaic approach. London: National 743 Children’s Bureau/Joseph Rowntree Foundation.

744 Coalter F, Allison M, \& Taylor J. (2000). The role of sport in regenerating deprived areas. Edinburgh: 745 SECRU.

746 Coote, A., Allen, J., \& Woodhead, D. (2004). Finding out what works: Building knowledge about 747 complex, community-based initiatives, London: The Kings Fund.

748 Crabbe, T. (2006a). Knowing the score, Positive Futures case study research: Final report. London: 749 Home Office.

750 Crabbe, T. (2006b). Going the distance: Impact, journeys and distance travelled (Positive Futures case

751 study research report). Retrieved from http://www.positivefuturesresearch.org.uk.

752 Damon, W. (2004) What is positive youth development? Annals of the American Academy, 59, 13-24. 
Running head: PYD, physical activity interventions and sustained impact

753 Davies, B. (2005). Threatening youth revisited: Youth policies under New Labour. The encyclopaedia 754 of informal education. Retrieved from

755 http://www.infed.org/archives/bernard_davies/revisiting_threatening_youth.html

756 DCSF (2005). Every Child Matters: aims and outcomes. Retrieved from

757 http://www.everychildmatters.gov.uk/aims

758 DCMS / DfES (2007). Departmental report. Norwich: HMSO.

759 DfEE (2000). How to evaluate education initiatives: A guide for schools. Nottingham: DfEE

760 Publications.

761 DfES (2003a). Permanent exclusions from schools and exclusion appeals, England 2001/2002

762 Provisional (SFR 16/2003). London: National Statistics.

763 DfES (2003b). Pupil absence in schools in England 2002/3 Revised (SFR 34/2003). London: National 764 Statistics.

765 DfES (2003c). Every child matters. London: Stationery Office.

766 DfES/DCMS (2004). High quality PE and sport for young people. Nottingham: DfES Publications.

767 Dillon, J., Morris, M., O’Donnell, L., Rickinson, M. \& Scott, W. (2005). Engaging and learning with

768 the outdoors: The final report of the outdoor classroom in a rural context action research project.

769 Bath: Centre for Research in Environmental Education.

770 Donnelly, P., \& Coakley, J. (2002). The role of recreation in promoting social inclusion. Toronto: 771 Laidlaw Foundation.

772 DSS (1999). Opportunity for all: Tackling poverty and social exclusion. London: TSO.

773 Eley, D. and Kirk, D. (2002) 'Developing Citizenship Through Sport: The Impact of a Sport-

774 Based Volunteer Programme on Young Leaders’ in Sport, Education and Society. Vol. 7 (2) pp 151775166.

776 Ennis, C. D. (1999). Creating a culturally relevant curriculum for disengaged girls. Sport, Education 777 and Society, 4(1), 31-49. 
Running head: PYD, physical activity interventions and sustained impact

778 Ennis, C.D., Solmon, M.A., Satina, B. Loftus, S.J., Mensch, J., \& McCauley, M.T. (1999). Creating a

779 sense of family in urban schools using the "Sport for Peace” Curriculum. Research Quarterly for

$780 \quad$ Exercise and Sport, 70, 273-285.

781 France, A. (2007). Understanding Youth in Late Modernity. Buckingham: Open University Press

782 France, A., Sutton, A., Sandu A,.\& Waring, A. (2007). Making a positive contribution: the implications

783 for youth work of every child matters. The National Youth Agency Research Programme Series.

784 http://www.crsp.ac.uk/downloads/publications/alans_publications/making_a_positive_contribution.pd

785 f Accessed 15th June 2010.

786 Garst, B., Schneider, I. \& Baker, D. (2001). Outdoor adventure program participation impacts on

787 adolescent self-perception. Journal of Experiential Education, 24, 41-50.

788 Gibbons, S.L., Ebbeck, V., \& Weiss, M.R. (1995). Fair Play for Kids: Effects on the moral

789 development of children in physical education. Research Quarterly for Exercise and Sport, 66, 247-

790255.

791 Glaser, B. G., \& Strauss, A.L. (1967). The discovery of grounded theory: Strategies for qualitative

792 research. New York: Aldine de Gruyter.

793 Golden, S., Lines, A., \& Sims, D. (2002). Mentor points: Pilot year evaluation (DfES Research Report 794 369). London: DfES.

795 Harper, D. (2002) Talking about pictures: A case for photo elicitation. Visual Studies, 17(1), 13-26.

796 Hattie, J., Marsh, H.W., Neill, J.T. \& Richards, G.E. (1997). Adventure education and Outward Bound:

797 out-of-class experiences that make a lasting difference, Review of Educational Research. 67(1), 43-

79887.

799 Hellison, D. (1995). Teaching responsibility through physical activity. Champaign, IL: Human

$800 \quad$ Kinetics.

801 Hellison, D., \& Walsh, D. (2003). Responsibility-based youth program evaluation: Investigating the

802 Investigations. Quest, 54, 292-307. 
Running head: PYD, physical activity interventions and sustained impact

803 Hellison, D., Martinek, T. \& Walsh, D. (2008) Sport and responsible leadership among youth. In, N.

804 Holt (Ed. ) Positive youth development (pp.49-60). London: Routledge.

805 Holt, N.L. (2008) Positive youth development through sport. London: Routledge.

806 Holt, N.L. \& Sehn, Z.L. (2008) Processes associated with positive youth development and participation

807 in competitive youth sport. In, N. Holt (Ed. ) Positive youth development (pp.24-33). London:

808 Routledge.

809 Holt, N.L. \& Jones, M.I. (2008) Future directions for positive youth development and sport research.

810 In, N. Holt (Ed. ) Positive youth development (pp.122-132). London: Routledge.

811 Lerner, R.M., Lerner, J.V., Almerigi, J.B. Theokas, C., Phelps, E., Naudeau, S., et al. (2005) Positive

812 youth development, participation in community youth development programs, and community

813 contributions of fifth grade adolescents: Findings from the first wave of the 4-H study of Positive

814 Youth Development. Journal of Early Adolescence, 25: 17-71.

815 Long, J. \& Sanderson, I. (2001). The social benefits of sport: Where’s the proof?. In, C. Gratton \& I. P.

816 Henry (Eds.), Sport in the city: The role of sport in economic and social regeneration (pp.187-203).

817 London: Routledge.

818 Long, J., Welch, M., Bramham, P., Butterfield, J., Hylton, K., \& Lloyd, E. (2002). Count me in: The 819 dimensions of social inclusion through culture, media \& sport. Leeds: Leeds Metropolitan University. 820 MacPhail, A., Kirk, D. \& Kinchin, G. (2004) Sport Education: Promoting team affiliation through 821 physical education, Journal of Teaching in Physical Education, 23(2), 106-122.

822 Martinek, T. J., \& Hellison, D. R. (1997). Fostering resiliency in underserved youth through physical 823 activity. Quest , 49(1), 34-49.

824 Miller, S. C., Bredemeier, B. J. L., \& Shields, D. L. L. (1997). Sociomoral education through physical 825 education with at-risk children. Quest, 49(1), 114-129.

826 Morris, L., Sallybanks, J., Willis, K., \& Makkai, T. (2003). Trends and issues in crime and criminal 827 justice. Australian Institute of Criminology. Retrieved from

828 http://www.aic.gov.au/publications/tandi/tandi249.html 
Running head: PYD, physical activity interventions and sustained impact

829 Neill, J. T., \& Dias, K. L. (2001). Adventure Education and Resilience: The Double-

830 Edged Sword. Journal of Adventure Education and Outdoor Learning, 1(2), 35-42.

831 Newburn, T. \& Shiner, M. (2005). Dealing with disaffection: Young people mentoring and social

832 inclusion. London: Willan Publishing.

833 Newton, M., Sandberg, J. \& Watson, D. (2001). Utilizing adventure education within the model of 834 moral action. Quest. 53, 483-494.

835 Nichols, G. (1997). A consideration of why active participation in sport and leisure might reduce 836 criminal behaviour, Sport, Education and Society. 2(2), 181-190.

837 Oliver, K. L. \& Lalik, R. (2001) The body as curriculum: Learning with adolescent girls, Journal of 838 Curriculum Studies, 33(3), 303-333.

839 Peacock, A. (2006). Changing minds: The lasting impact of school trips. Retrieved from

840 http://www.nationaltrust.org.uk/main/w-schools-guardianships-changing_minds.pdf

841 Petitpas, A. Cornelius, A. \& Van Raalte, J. (2008) Youth development through sport. In, N.Holt (Ed.)

842 Positive youth development and sport (pp.61-70). London: Routledge.

843 Pitter, R., \& Andrews, D. L. (1997). Serving America’s underserved youth: Reflections on sport and

844 recreation in an emerging social problems industry. Quest 49(1), 85-99.

845 Reid, K. (2002). Mentoring with disaffected pupils. Mentoring and Tutoring, 10(2), 153-169.

846 Richardson, L.D., \& Wolfe, M. (2001). The principles and practice of informal education: Learning 847 through life. London: Routledge Falmer.

848 Riley, K. A., \& Rustique-Forrester, E. (2002). Working with disaffected students. London: Paul 849 Chapman.

850 Rossi, P.H.; Lipsey, M.W.; Freeman, H.E (2005). Evaluation. A Systematic Approach $7^{\text {th }}$ Edition. 851 London: Sage.

852 Ruiz, J. (2004), A Literature Review Of The Evidence Base For Culture, The Arts And Sport Policy, 853 Scottish Government, website accessed 22 October 2009

854 http://www.scotland.gov.uk/Publications/2004/08/19784/41510 
Running head: PYD, physical activity interventions and sustained impact

855 Russell, I. M. (2005) A National Framework for Youth Action and Engagement. London: HMSO.

856 Sandford, R.A., Armour, K.M. \& Warmington, P.C. (2006). Re-engaging disaffected youth through 857 physical activity programmes. British Educational Research Journal, 32(2), 251-271.

858 Sandford, R., Armour, K. \& Duncombe, R. (2008a). Physical activity and personal/social development 859 for disaffected youth in the UK: In search of evidence. In, N. Holt (Ed.) Positive youth development 860 through sport (pp.97-108). London: Routledge.

861 Sandford, R.A., Duncombe, R. \& Armour, K.M. (2008b) The role of physical activity/sport in tackling 862 youth disaffection and anti-social behaviour. Educational Review, 60(4), 419-435.

863 SEU (Social Exclusion Unit) (2000). National strategy for neighbourhood renewal. Report of Policy 864 Action Team 12: young people. Retrieved from

865 http://www.socialexclusionunit.gov.uk/downloaddoc.asp?id=125/

866 Shiner, M.,, Young, T., Newburn, T. \& Groben, S. (2004). Mentoring disaffected young people: an 867 evaluation of 'Mentoring Plus' $16^{\text {th }}$ June. Joseph Rowntree Publications, $16^{\text {th }}$ June.

868 http://www.jrf.org.uk/publications/mentoring-disaffected-young-people-evaluation-mentoring-plus.

869 Accessed 15th June 2010.

870 Siedentop, D. (1994). Sport Education: Quality PE through positive sport experiences. Champaign, IL:

871 Human Kinetics.

872 Smink, J. (2000). Foreword. In R. Klein, Defying disaffection: How schools are winning the hearts and 873 minds of reluctant students. Stoke on Trent, UK: Trentham Books.

874 Stake, R. (2005).Multiple Case Study Analysis, London: Guildford Press.

875 Spencer, L., Ritchie, J., Lewis, J., \& Dillon, L. (2003). Quality in qualitative evaluation: A framework 876 for assessing research evidence. London: National Centre for Social Research.

877 Steer, R., (2000). A background to youth disaffection: A review of literature and evaluation findings 878 from work with young people. London: Community Development Foundation.

879 Strauss, A. L., \& Corbin, J. (1998). Basics of qualitative research: Techniques and procedures for 880 developing grounded theory (2nd edition). Thousand Oaks, CA: Sage Publications. 
Running head: PYD, physical activity interventions and sustained impact

881 Theodoulides A. \& Armour. K. M. (2001) 'Personal, Social and Moral Development Through Team 882 Games: Some critical questions’, European Physical Education Review, 7 (1), pp.5-23.

883 Vulliamy, G. \& Webb R. 2003. Supporting disaffected pupils: Perspectives from the pupils, their 884 parents and their teachers. Educational Research, 45(3), 275-286.

885 Yin, R.K. (1984). Case Study Research: Design and methods. London: Sage Publications. 
Running head: PYD, physical activity interventions and sustained impact

Tables

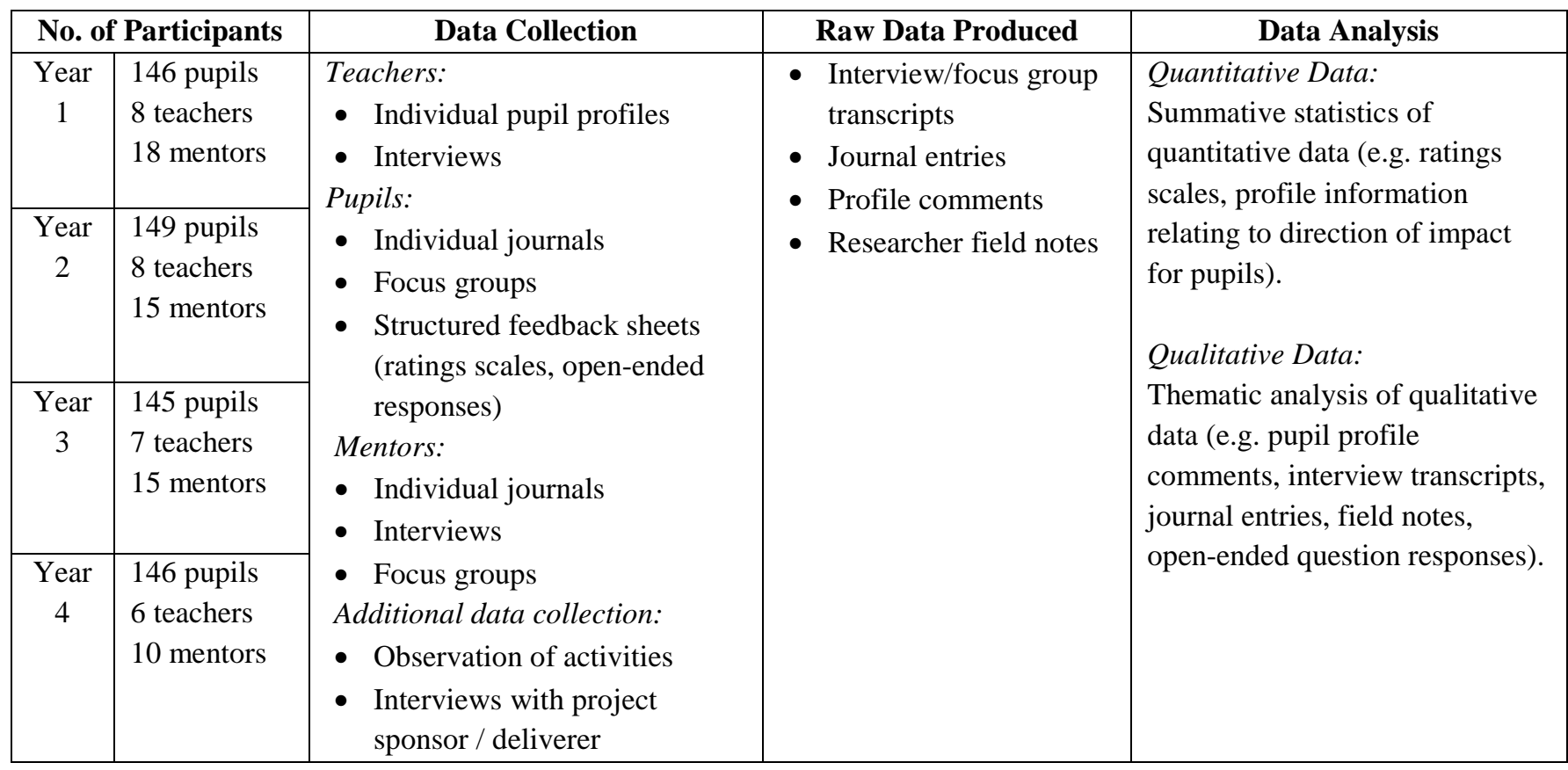

Table 1: Evaluation Summary for the HSBC/OB Project

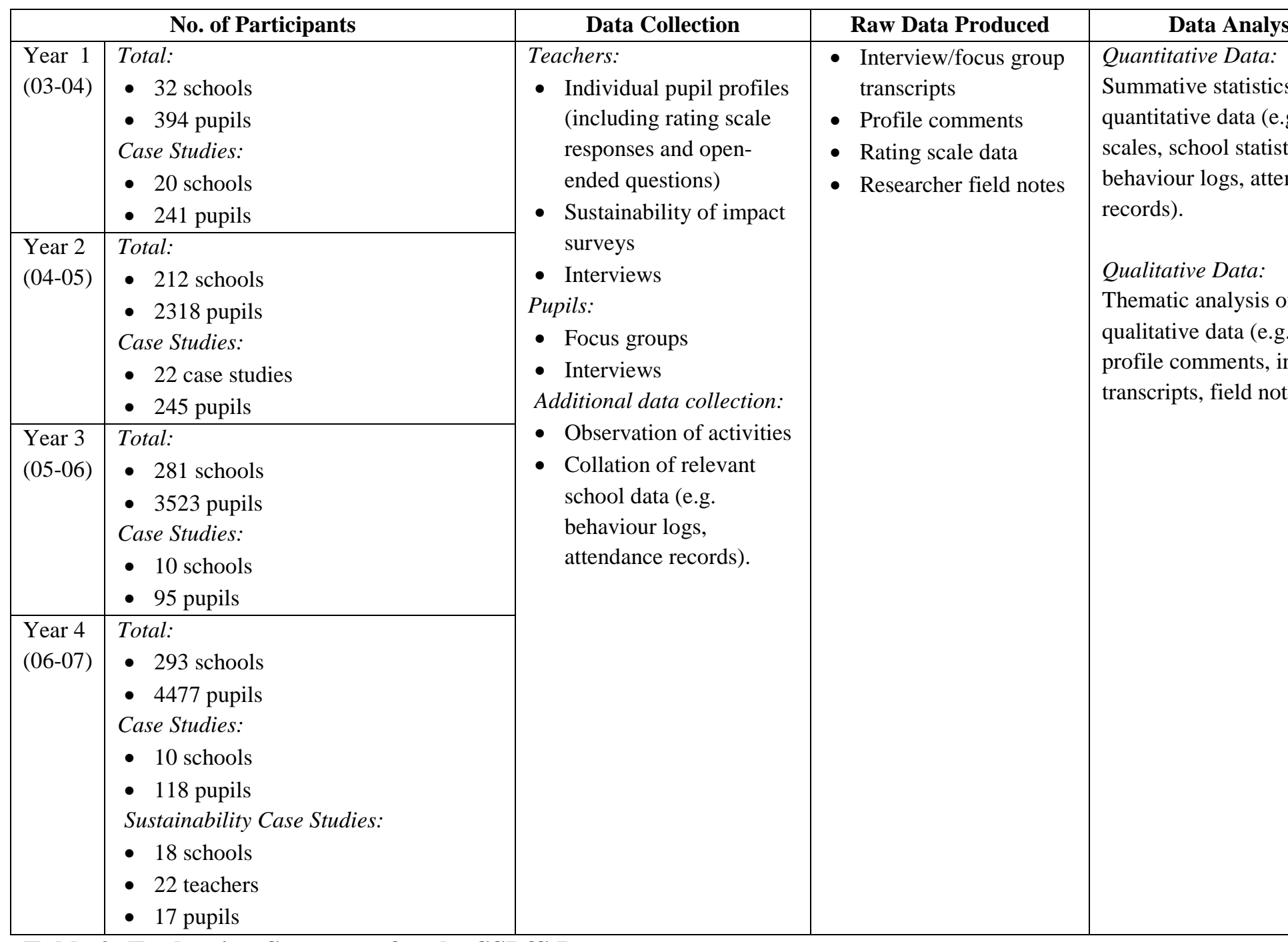


Running head: PYD, physical activity interventions and sustained impact

\begin{tabular}{|l|c|c|c|}
\hline \multicolumn{3}{|c|}{ Year 4 Findings } \\
\hline & $\begin{array}{c}\text { No. of pupils showing } \\
\text { improvements at end } \\
\text { of the project. }\end{array}$ & $\begin{array}{c}\text { No. of pupils } \\
\text { perceived to } \\
\text { maintain } \\
\text { improvements for } ~ \\
12 \text { months }\end{array}$ & $\begin{array}{c}\text { \% of pupils perceived to maintain } \\
\text { improvements for } ~ 12 \text { months }\end{array}$ \\
\hline $\mathbf{1 2}$ months & 497 & 433 & $87.1 \%$ \\
\hline 36 months & 110 & 100 & $90.9 \%$ \\
\hline
\end{tabular}

\section{Table 3: SSLfS: pupils showing sustained improvements (Year 4 Findings)}

Teachers' perceptions of the number of pupils who, after showing an initial improvement at the end of engagement in the

\begin{tabular}{|c|c|c|c|c|}
\hline \multirow{2}{*}{ All Schools } & \multicolumn{4}{|c|}{ Positive Improvement from Baseline (\% of pupils) } \\
\cline { 2 - 5 } & $\mathbf{6}$ months & $\mathbf{1 2}$ months & 24 months & 36 months \\
\hline Yr 1 & 68.4 & 71.4 & 65.4 & 56.25 \\
\hline Yr 2 & 58.0 & 57.8 & 60.5 & 41.5 \\
\hline Yr 3 & 47.7 & 61.0 & 45.5 & 83.0 \\
\hline (All Years) & 58.0 & 63.4 & 57.1 & 69.6 \\
\hline
\end{tabular}

\section{Table 4: HSBC/OB: Pupils showing sustained improvements (Years 1, 2 and 3)}

Table showing the number of pupils showing a positive change from baseline (as perceived by teachers) in Years 1, 2 and 3 
Running head: PYD, physical activity interventions and sustained impact

Appendix A Basic Logic Model for the HSBC/Outward Bound Project

\begin{tabular}{|c|c|c|c|c|c|c|}
\hline \multicolumn{4}{|c|}{$\begin{array}{l}\text { YOUR PLANNED WORK } \\
\text { (i.e. what you are planning to do) }\end{array}$} & \multicolumn{3}{|c|}{$\begin{array}{l}\text { YOUR INTENDED RESULTS } \\
\text { (i.e. what you are expecting to happen) }\end{array}$} \\
\hline \multicolumn{2}{|c|}{$\begin{array}{l}\text { RESOURCES/INPUT } \\
\text { i.e. elements/factors influencing your ability to do } \\
\text { work (positive or negative) }\end{array}$} & \multicolumn{2}{|c|}{$\begin{array}{l}\text { ACTIVITIES } \\
\text { i.e. what you then do with your resources }\end{array}$} & $\begin{array}{l}\text { OUTPUTS } \\
\text { i.e. the direct product } \\
\text { of your activities }\end{array}$ & $\begin{array}{l}\text { OUTCOMES } \\
\text { i.e. the changes to } \\
\text { participants' behaviour } \\
\text { (as a result of the } \longrightarrow \\
\text { programme) }\end{array}$ & $\begin{array}{l}\text { IMPACT } \\
\text { i.e. the fundamental } \\
\text { changes in } \\
\text { organisations, } \\
\text { systems, } \\
\text { communities etc. as } \\
\text { a result of the } \\
\text { programme }\end{array}$ \\
\hline $\begin{array}{l}\text { Finances } \\
\text { Inter-personal } \\
\text { networks }\end{array}$ & $\begin{array}{l}\text { HSBC funding } \\
\text { HSBC-OB relations } \\
\text { HSBC-school relations }\end{array}$ & \multirow{3}{*}{$\begin{array}{l}\text { Activities: } \\
\text { Book facilities } \\
\text { Arrange evaluation } \\
\text { Arrange steering group } \\
\text { meetings } \\
\text { Select schools } \\
\text { Select young people } \\
\text { Launch/Closure days } \\
\text { OB courses } \\
\text { Weekend course event } \\
\text { Classic course event } \\
\text { Follow-up activities }\end{array}$} & \multirow{3}{*}{$\begin{array}{l}\text { Led by: } \\
\text { OB } \\
\text { HSBC } \\
\text { HSBC } \\
\text { HSBC } \\
\text { School staff } \\
\text { OB } \\
\text { OB } \\
\text { OB } \\
\text { OB } \\
\text { Mentors and } \\
\text { school staff } \\
\text { [NB. No clear } \\
\text { indication of } \\
\text { who takes the } \\
\text { lead here] }\end{array}$} & \multirow{3}{*}{$\begin{array}{l}\text { Programmes developed } \\
\text { Programmes/events } \\
\text { run: } \\
\text { - Launch day } \\
\text { - Weekend course } \\
\text { - Classic course } \\
\text { Follow-up activities }\end{array}$} & \multirow{3}{*}{$\begin{array}{l}\text { Young people are re- } \\
\text { engaged } \\
\text { Decreased disaffected } \\
\text { behaviour } \\
\text { Increased community } \\
\text { involvement } \\
\text { Young people as role } \\
\text { models within schools } \\
\text { [different people in the } \\
\text { partnership may have } \\
\text { different ideas here] } \\
\text { Also changes for: } \\
\text { HSBC, OB, Teachers, } \\
\text { Mentors etc. }\end{array}$} & \multirow{3}{*}{$\begin{array}{l}\text { Young people as } \\
\text { role models in the } \\
\text { community } \\
\text { Increased academic } \\
\text { achievement } \\
\text { Mentor relations } \\
\text { with schools } \\
\text { HSBC community } \\
\text { relations } \\
\text { OB corporate } \\
\text { relation }\end{array}$} \\
\hline People & $\begin{array}{l}\text { HSBC link } \\
\text { Out. Bound Link } \\
\text { Instructors (Inst) } \\
\text { School staff (Staff) } \\
\text { Mentors (Ment) }\end{array}$ & & & & & \\
\hline $\begin{array}{l}\text { Facilities } \\
\text { Equipment }\end{array}$ & $\begin{array}{l}\text { Outward Bound Centres } \\
\text { Schools } \\
\text { HSBC HQ }\end{array}$ & & & & & \\
\hline
\end{tabular}


Running head: PYD, physical activity interventions and sustained impact

\section{Appendix B \\ Illustrative Example of the Data Analysis Process: Case Study Data}

\begin{tabular}{|c|c|c|c|c|c|}
\hline Process & Raw Data & Initial Review of Data & Coding / Memo Writing & $\begin{array}{l}\text { Identifying Points of } \\
\text { Commonality }\end{array}$ & Generation of Themes \\
\hline Explanation & \begin{tabular}{ll}
\multicolumn{2}{l}{ Collate all raw data } \\
- & Interview data (transcripts) \\
- & Journal entries \\
- & Profile data \\
- & Researcher fieldnotes
\end{tabular} & $\begin{array}{l}\text { Scan through the data } \\
\text { and highlight points of } \\
\text { immediate interest } \\
\text { (considering perceived } \\
\text { relevance to the research } \\
\text { questions or project } \\
\text { aims/objectives). }\end{array}$ & $\begin{array}{l}\text { Review the highlighted data } \\
\text { and begin to identify } \\
\text { categories or codes by picking } \\
\text { out key words/phrases. } \\
\text { Alongside, make notes } \\
\text { (memos) to explain the } \\
\text { identification of codes. }\end{array}$ & $\begin{array}{l}\text { Review the codes (and } \\
\text { associated memos) and begin } \\
\text { to make links between them. } \\
\text { Also identify links between } \\
\text { the data and literature, and } \\
\text { different cohorts of data. }\end{array}$ & $\begin{array}{l}\text { Group the codes / categories into } \\
\text { clusters (themes) according to } \\
\text { points of commonality. }\end{array}$ \\
\hline $\begin{array}{l}\text { Illustration } \\
\text { [from } \\
\text { HSBC/OB } \\
\text { project] }\end{array}$ & $\begin{array}{l}\text { Alan (teacher) commented that a } \\
\text { lot of his pupils seemed to do } \\
\text { quite well initially as a result of } \\
\text { taking part in the project, but he } \\
\text { also said that those who } \\
\text { continued to show improvements } \\
\text { (e.g. in confidence and ability) } \\
\text { were the ones who were } \\
\text { motivated enough to get involved } \\
\text { in other things like DofE and } \\
\text { Young Enterprise. } \\
\text { [researcher fieldnotes] }\end{array}$ & $\begin{array}{l}\text {...lot of pupils seemed to } \\
\text { do quite well initially... } \\
\text {... those who continued } \\
\text { to show improvements... } \\
\text { were motivated enough } \\
\text { to get involved in other } \\
\text { things }\end{array}$ & $\begin{array}{l}\text { Continued Involvement } \\
\text { Important } \\
\text { e.g. “... those who continued } \\
\text { to show improvements... were } \\
\text { motivated enough to get } \\
\text { involved in other things" } \\
\text { [Memo: highlights the } \\
\text { perceived need for pupils to } \\
\text { keep involved in similar } \\
\text { activities if improvements } \\
\text { aren't to be temporary] }\end{array}$ & $\begin{array}{l}\text { Suggests that pupils need } \\
\text { further opportunities to use, } \\
\text { apply and develop skills } \\
\text { acquired through initial } \\
\text { project involvement. } \\
\text { Pupil focus group data (e.g. } \\
\text { school E) also supports this. } \\
\text { Links to literature on } \\
\text { transferability of skills (e.g. } \\
\text { Holt et al. 2008) }\end{array}$ & $\begin{array}{l}\text { Key Theme } \\
\text { Structured pathways to enable } \\
\text { sustained involvement in project } \\
\text { activities (or complementary } \\
\text { activities) are important }\end{array}$ \\
\hline
\end{tabular}

\section{Illustrative Example of the Data Analysis Process: Pupil Profiles}

\begin{tabular}{|c|c|c|c|c|}
\hline Explanation & $\begin{array}{l}\text { Collate raw data } \\
\text { (teacher feedback forms) }\end{array}$ & $\begin{array}{l}\text { Identify data relating to } \\
\text { numbers of pupils }\end{array}$ & $\begin{array}{l}\text { Calculate the percentage of total pupils showing } \\
\text { particular types of improvements (e.g. } \\
\text { positive/negative) }\end{array}$ & Present Findings \\
\hline $\begin{array}{l}\text { Illustration [from } \\
\text { SSLfS project - } \\
\text { Sustainability of } \\
\text { Impact Forms] }\end{array}$ & $\begin{array}{l}\text { Teachers were asked to } \\
\text { provide data for the } \\
\text { number of pupils who } \\
\text { showed initial } \\
\text { improvements and for } \\
\text { how many sustained these } \\
\text { improvements over time. }\end{array}$ & $\begin{array}{l}\text { Figures were extracted for } \\
\text { pupils who had finished } \\
\text { their projects 12, } 24 \text { and } \\
36 \text { months ago. }\end{array}$ & $\begin{array}{l}\text { Total number of pupils showing an initial } \\
\text { improvement was } 110 \text {. } \\
\text { Total number of pupils showing a sustained } \\
\text { improvement was } 100 \text {. } \\
\text { Percentage of pupils sustaining improvements was } \\
\text { therefore } 90.9 \% \text {. }\end{array}$ & $\begin{array}{l}\text { "90.9\% of pupil who were perceived by } \\
\text { their teachers to have made an initial } \\
\text { improvement were seen to sustain this } \\
\text { improvement over a period of } 36 \\
\text { months" }\end{array}$ \\
\hline
\end{tabular}

